\title{
Water balance of Lake Gardno
}

\author{
Izabela Chlost \\ Department of Hydrology, Institute of Geography, University of Gdańsk, Bażyńskiego 4, 80-309 Gdańsk, Poland, \\ e-mail: izabela.chlost@ug.edu.pl
}

\begin{abstract}
The article describes the characteristics of water circulation in the coastal Lake Gardno. The water cycle is based on water balance data calculated for the period 2003-2007 concerning hydrological years, including the components of horizontal and vertical exchange. Due to the coastal location of the lake, particular attention was paid to the share of the seawater in the lake water cycle. It was found that the inflow of sea water accounts for $10 \%$ of the total inflow, while inflow from the land accounts for $86 \%$ of the total.
\end{abstract}

Key words: water cycle, coastal lake, hydraulic contact

\section{Introduction}

Water exchange in lakes, which results in changes in reservoir retention, results from the dynamic water balance (Rockstrom 2013). Changes in retention, however, are expressed through the variability of the water level (Bajkiewicz-Grabowska 2002). Hence, the standard equation of a lake's water balance includes vertical and horizontal exchange streams, including the income components of atmospheric precipitation on the water surface $(P)$, and surface and underground inflow of waters from the catchment $(H d)$, as well as water outflow components, which consist of evaporation from the water body surface $(E)$ and outflow $(H w)$. The balance equation is closed by the retention difference corresponding to the lake capacity change at the beginning and end of the balance period (Mikulski 1970a).

However, today this is one of the least researched elements in hydrology. The existing water balance calculations concern mainly large lakes (Lichter 1995; Yin and Nicholson 1998; Zangh et al. 2016). Smaller lakes are disregarded due to the lack of a monitoring system, which in turn is associated with the lack of sufficient data. Another reason is the complicated water cycle and the uncertainty respecting the number of components needed to calculate such a balance. This mainly applies to the coastal zone of seas and oceans. Here, apart from the elements that are permanent for all lakes (precipitation, evaporation, underground and surface inflow and outflow), new components appear (surface and underground intrusions of sea waters) (Appelo and Willem- sen 1987), for which there is often no reliable data. This is particularly true of groundwater inflow (Burnett et al. 2001), with particular regard to saltwater intrusion (Recinos et al. 2015).

Another problem is the difficulty in choosing a method for calculating evaporation. Recently some new approaches have appeared, e.g. using systematic isotopic patterns in surface waters (Gibson and Edwards 2002). This method allows regional differences in losses caused by evaporation to be determined and has already been applied to different climatic conditions as well as geographical locations and altitudes (Gibson et al. 2016). Another helpful solution is the use of mathematical and hydrological models. For example, studies on the development and application of monthly water balance models have been conducted since the 1940s. Monthly water balance models were initially introduced to assess the significance of selected parameters under various hydrological conditions. Current applications of water balance models are oriented in three main directions: reconstruction of catchment hydrology, climate change assessment and seasonal and geographical water demand patterns (Xu and Singh 1998). In the case of constant measurements of water level changes, it is now possible to use satellite data that allows changes in water levels in the sea and lakes to be tracked (Crétaux et al. 2011).

In the case of coastal lakes, which are also called transiently open/closed estuaries or sporadically closed and open lakes and lagoons (Jones et al. 2018), the process of water exchange and its size is co-decided by the 


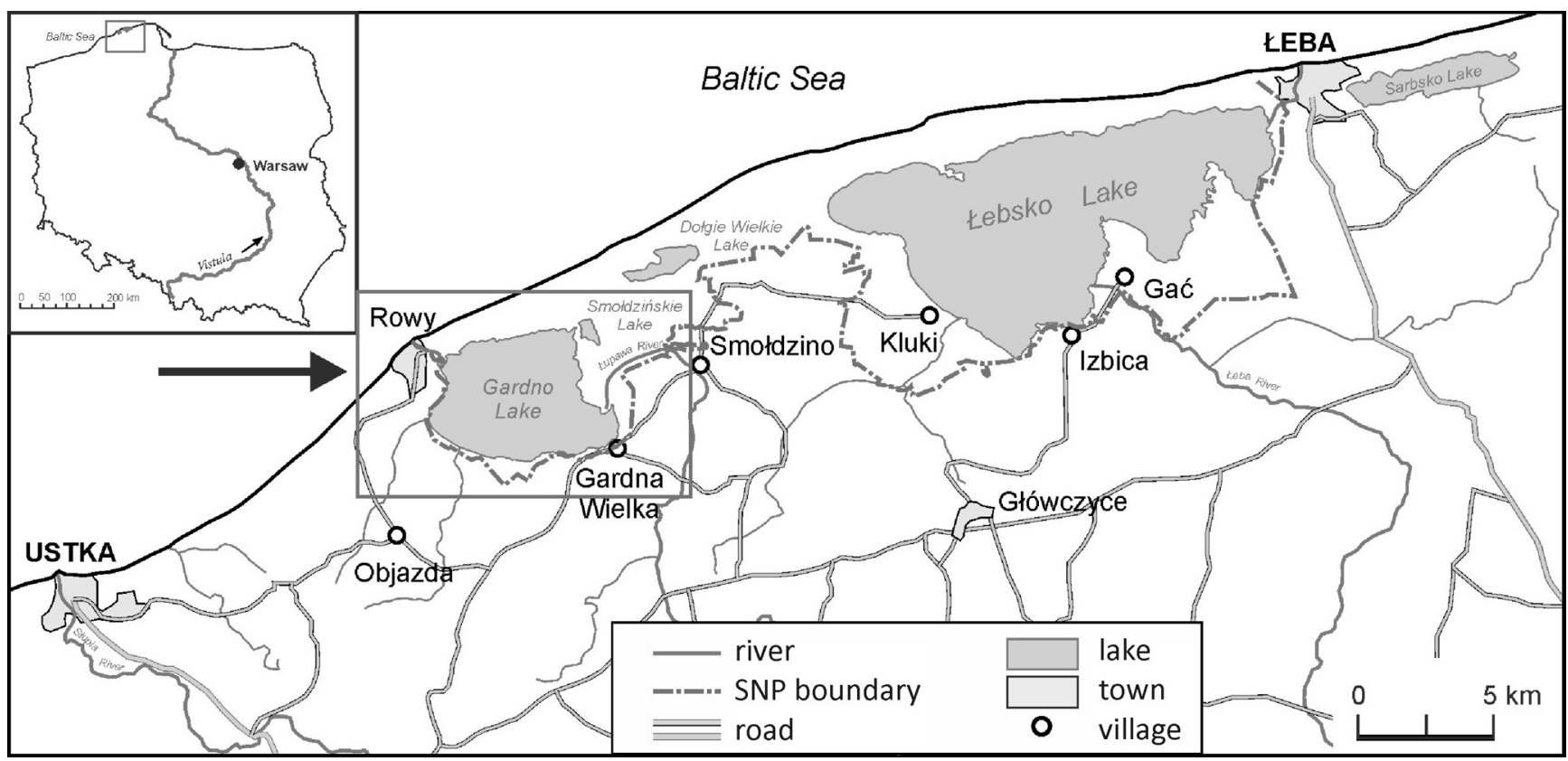

Fig. 1. Location of the study area

location of the reservoir in the coastal zone. Lake Gardno, which is the subject of research, lies on the coast of the South Baltic (Fig. 1). The lake is a recipient of waters flowing into it from its total and immediate basin. The water reaches the lake in a natural or forced manner from the surrounding polders. In favourable air pressure conditions, seawater inflows into the lake as a result of intrusion. This is thanks to the mouth section of the River Łupawa which connects the lake with the sea. In this situation the composition of the lake's water balance is extended by an additional element, which is alimentation from the sea $(\mathrm{Hm})$. The following equation represents its mathematical form:

$$
(P-E)+(H d+H m-H w)=\Delta R,
$$

where: $P$ - atmospheric precipitation, $E$ - evaporation from the water surface, $H d$ - surface and underground water inflow, $\mathrm{Hm}$ - seawater inflow, $\mathrm{Hw}$ - surface and underground water outflow, $\Delta R$ - retention difference

The connection of the lake with the main drainage base (the sea) determines the hydraulic contact of both water bodies, expressed in a synchronous course of fluctuations in the level of the lake and the sea. The way the sea affects the lake depends on the current difference in the water levels between them. Therefore, we may observe a phenomenon which supports the outflow of water from the lake as a result of high sea level (blocked discharge) or the creation of an inverted gradient and the flow of water from the sea towards the lake. In Lake Gardno, this provokes certain quantitative and qualitative repercussions. The role of the sea basin in shaping the water cycle in the lake boils down to the formation of outflow conditions from the lake or the real, periodically occurring share of sea water in the water balance.

In reference to the above, the paper aims to determine the structure of the water cycle in Lake Gardno, taking into account the volume of vertical and horizontal exchange streams. This involves a numerical specification of individual components taking part in the balance as well as an indication of the relations between them and seasonal fluctuations in the water level in the lake. It is primarily the recognition of the size of lake alimentation from the sea, indicating the periods in which sea waters have a decisive role in shaping the balance.

\section{Methods}

The water balance of Lake Gardno for the hydrological years 2003-2007 is presented. The estimation of its components was based on the selected meteorological and hydrological elements from the database of the Institute of Meteorology and Water Management PIB and a meteorological station in the village of Gać owned by the Institute of Geography of the Pomeranian Academy in Słupsk. The study uses daily data. The amount of atmospheric supply was determined based on the precipitation totals from the following stations: Ustka, Objazda, Smołdzino, Kluki, Izbica and Łeba. Evaporation from the water surface was calculated from the Davidov formula (Kossowska-Cezak and Bajkiewicz-Grabowska 2009). For this purpose, data from the coastland stations in Ustka and Łeba as well as from the station in Gać were used. The applied formula contained only two 
elements; air saturation deficit and wind velocity and is given by the following equation:

$$
E=0.4 d(1+0.25 v)
$$

where: $E$ - daily evaporation from the water surface $(\mathrm{mm}), d$ - average daily air saturation deficit $(\mathrm{mm} \mathrm{Hg})$, and $v$-average daily wind speed $\left(\mathrm{m} \mathrm{s}^{-1}\right)$. In the periods of full ice formation, the simplified Ostromęcki formula was used $(E=0.63 \mathrm{~d})$.

The volume of inflow of potamic waters to the lake was based on the daily values of the flow of the River Eupawa in the Smołdzino profile. Due to the lack of permanent hydrometric measurements on the other streams supplying Lake Gardno, their share in the water balance was omitted. The inflow to the lake was, however, supplemented with the discharge from five active polders located around the lake, as well as the lateral inflow from the immediate catchment, calculated from the monthly average outflows of the river subjected to hydrometric control (Łupawa). The volumes obtained in this way from the direct basin were reduced by the values of discharges from the pumping station to separate the gravity outflow from the forced one. Intrusions of marine waters into the lake were estimated for periods in which the level of the Baltic Sea in the Ustka port was higher than the level of the lake in Gardna Wielka.
These periods were determined by comparing the level of both basins after reducing data to a common reference point - zero of the water gauge. This method was successfully used before (Mikulski 1970b; Mikulski et al. 1969; Balicki 1978). To determine the volume of seawater inflow it was assumed that during the intrusion, the outflow of water from the basin is stopped (which increases its volume in the lake basin), and the surface of the lake does not change despite fluctuations in water levels (Weber 1973). The inflow volume was obtained after deducting the atmospheric inflow, as well as the inflow from the lake basin and the immediate basin.

A lack of observed changes in the level of groundwater in the vicinity of Lake Gardno caused difficulties in determining underground alimentation and outflow. For this reason, it was considered that these components were balanced and thus were omitted. The outflow from the lake was calculated from the balance equation. Balance data was presented in three reference units: water volume $\left[\mathrm{hm}^{3}\right]$, water layer $[\mathrm{mm}]$ and percent, and were presented as the average annual value and monthly averages from the period 2003-2007.

\section{Study area}

Gardno Lake is one of the few coastal lakes in the Polish zone of the Southern Baltic and the second largest.

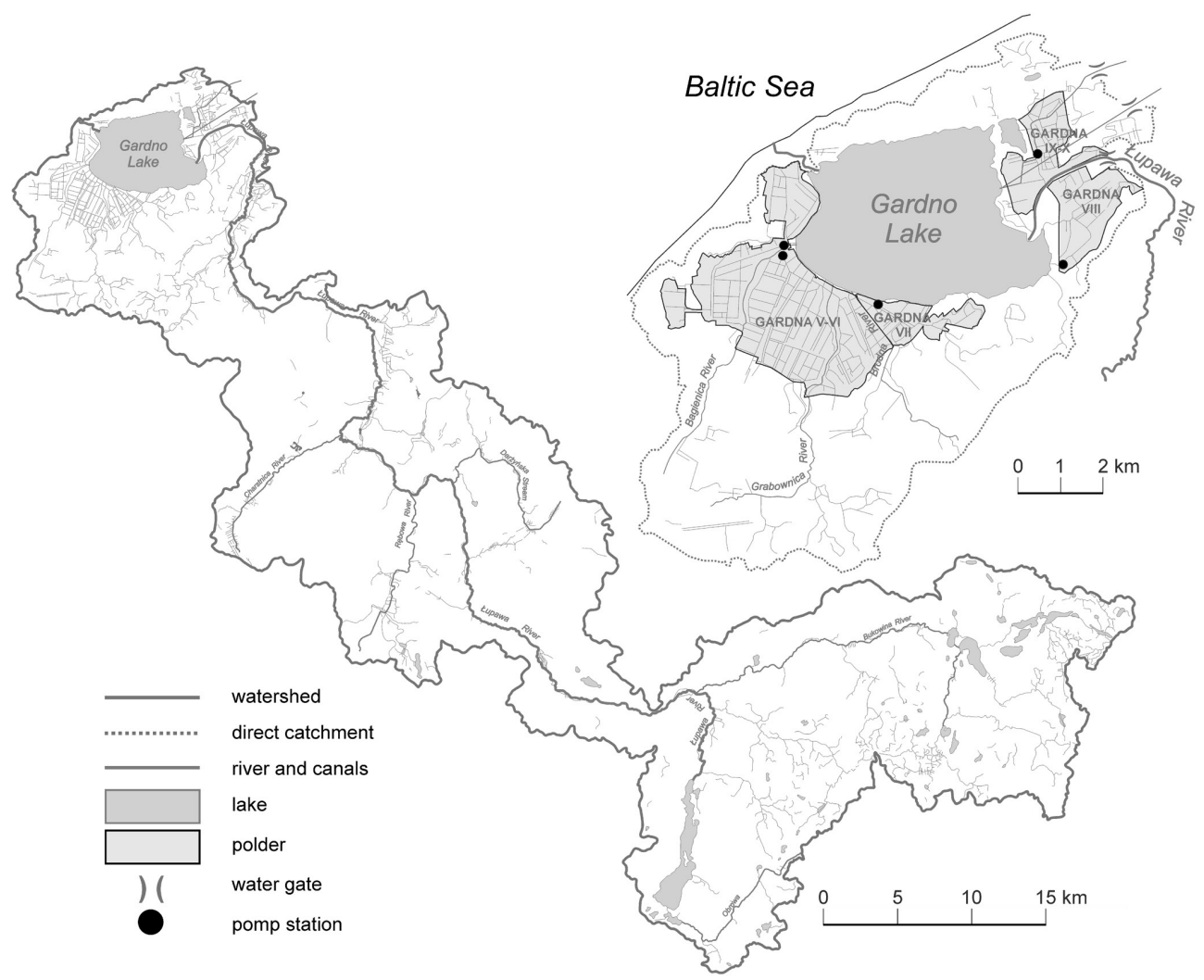

Fig. 2. Hydrographic sketch of the Łupawa catchment and direct catchment of Lake Gardno 
It is located within the limits of the Slovincian National Park, SNP (Słowiński Park Narodowy) in the geomorphological unit known as the Gardno-Łeba Lowland. The lake is surrounded from the south and west by the moraine of the Gardno lob, and from the north separated from the Baltic Sea by the sandy embankment of the Łeba Spit (Rotnicki 2008). The eastern shore of the lake is formed by an inflow fan of the River Łupawa. The immediate surroundings of the lake are taken up by wetlands. Several rivers flow into the lake, the largest of which is the Eupawa. It creates a basin with an area of $925 \mathrm{~km}^{2}$, which almost entirely constitutes the catchment of the lake. Leaving the lake, the river breaks through the dunes and feeds into the main drainage base. This section was partially regulated in the 1970 s, which is why it is often called a canal. At the junction of the canal with the sea there is a small seaport in Rowy. The remaining rivers flowing into the lake form its immediate catchment, with an area of $125.4 \mathrm{~km}^{2}$ (Cieśliński et al. 2009). These include the Bagienica, Grabownica and Brodna rivers. The immediate catchment is also formed by polders cut by a network of drainage ditches: Gardna V, Gardna V-VI, Gardna VII and Gardna IX-X (Fig. 2). The lake exibits a highly active hydrological system, manifesting itself through a high water exchange rate at the level 9.3 (Bogdanowicz and Cieśliński 2007).

The lake is shallow. Its average depth is $1.3 \mathrm{~m}$, and the maximum reaches only $2.6 \mathrm{~m}$ (Choiński 1991). The bottom of the lake is flat, covered with mud and a lay- er of sediments with a thickness of $2.5 \mathrm{~m}$. It covers an area of 2468 ha, constituting $20 \%$ of the immediate basin and is continuously shrinking. The surface of Lake Gardno is gradually being reduced due to overgrowth, the sediments delivered by the River Łupawa and aeolian processes. As a result, in its north-eastern part, Lake Smołdzińskie developed; its area is 28 ha, and average depth is $1.3 \mathrm{~m}$.

\section{Results}

Lakes located in the coastal zone are also dynamic coastal systems, which may be susceptible to changes in catchment hydrology (Sadat-Nooria et al. 2016). This was demonstrated by the water balance studies carried out on Lake Gardno. It turned out that the state of retention of the Lake Gardno basin is determined by the horizontal water exchange, while the vertical phase plays a marginal role. Similar results were obtained for the neighbouring Lake Łebsko (Chlost 2009. 2016). In the period $2003-$ 2007, the atmospheric exchange rate was balanced and amounted to several percents of the total volume of exchangeable water (Fig. 2). On average, $673 \mathrm{~mm}$ of rain fell on the surface of the lake, supplying it with $16.609 \mathrm{hm}^{3}$ of water. The largest pluvial supply values were recorded in the warm season with the maximum in July and August . Low precipitation was recorded from February to April (Table 1). The average evaporation value in the five-year study was $601 \mathrm{~mm}$, which was $14.852 \mathrm{hm}^{3}$ of water. The

Table 1. The average monthly water balance of Lake Gardno from the period 2003-2007

\begin{tabular}{|c|c|c|c|c|c|c|c|c|c|c|c|c|c|c|c|}
\hline & & ov & Dec & Jan & Feb & Mar & Apr & May & Jun & Jul & Aug & Sep & Oct & Nov-Apr & May-Oct \\
\hline \multirow{6}{*}{ 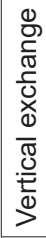 } & $n^{3}$ & 347 & 1.333 & .535 & 0.963 & 0.745 & 0.750 & 963 & 1.229 & 1.831 & 2.345 & 1.747 & 1.821 & 6.673 & 936 \\
\hline & $\mathrm{Pmm}$ & 55 & 54 & 62 & 39 & 30 & 30 & 39 & 50 & 74 & 95 & 71 & 74 & 270 & 403 \\
\hline & $\%$ & 8.1 & 8.0 & 9.3 & 5.8 & 4.5 & 4.5 & 5.8 & 7.4 & 11.0 & 14.1 & 10.5 & 11.0 & 0.2 & 59.8 \\
\hline & $\mathrm{hm}^{3}$ & 587 & 0.449 & .415 & 0.301 & 0.691 & 1.338 & 1.925 & 2.330 & 2.305 & 1.831 & 1.530 & 1.150 & 3.781 & 11.071 \\
\hline & $E \mathrm{~mm}$ & 24 & 18 & 17 & 12 & 28 & 54 & 78 & 94 & 93 & 74 & 62 & 47 & 153 & 448 \\
\hline & $\%$ & .0 & 3.0 & 2.8 & 2.0 & 4.7 & 9.0 & 13.0 & 15.7 & 15.5 & 12.3 & 10.3 & 7.7 & 5.5 & 74.5 \\
\hline \multirow{9}{*}{ 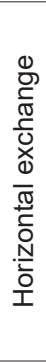 } & 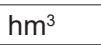 & .060 & .777 & 1.020 & 8.468 & 9.792 & 25.515 & 23.601 & 0.501 & 22.808 & 21.903 & 21.252 & 22.793 & 168.632 & 132.858 \\
\hline & $H_{d} \mathrm{~mm}$ & 056 & 1126 & 1257 & 1153 & 1207 & 1034 & 956 & 831 & 924 & 887 & 861 & 924 & 6833 & 33 \\
\hline & $\%$ & 8.6 & 9.2 & 10.3 & 9.4 & 9.9 & 8.5 & 7.8 & 6.8 & 7.6 & 7.3 & 7.0 & 7.6 & 55.9 & 44.1 \\
\hline & $\mathrm{hm}^{3}$ & 393 & 5.928 & 251 & 2.251 & 3.115 & 2.370 & 0.701 & 3.320 & 1.717 & 0.667 & 2.514 & 2.564 & 22.308 & 11.483 \\
\hline & $H_{m} \mathrm{mr}$ & 78 & 240 & 173 & 91 & 126 & 96 & 28 & 135 & 69 & 27 & 102 & 104 & & 5 \\
\hline & $\%$ & 3.0 & 17.5 & 12.6 & 6.7 & 9.2 & 7.0 & 2.1 & 9.8 & 5.1 & 2.0 & 7.4 & 7.6 & 66.0 & 4.0 \\
\hline & $\mathrm{hm}^{3}$ & .473 & 2.072 & 35.749 & 37.748 & .257 & 30.012 & 19.786 & 0.153 & 24.051 & 21.110 & 25.118 & 28.496 & 199.311 & 38.714 \\
\hline & $H_{w} \mathrm{mr}$ & 1235 & 1300 & 1449 & 1529 & 1347 & 1216 & 801 & 818 & 974 & 855 & 1018 & 1155 & 8076 & 5621 \\
\hline & $\%$ & .0 & 9.5 & 10.6 & 11.2 & 9.8 & 8.9 & 5.9 & 6.0 & 7.1 & 6.2 & 7.4 & 8.4 & 59.0 & 41.0 \\
\hline \multirow{2}{*}{$\begin{array}{l}\dot{0} \\
\not{\not}\end{array}$} & $\mathrm{hm}^{3}$ & 740 & 2.517 & 0.642 & -6.367 & -0.296 & -2.715 & 3.554 & 2.567 & 0.000 & 1.974 & -1.135 & -2.468 & -5.479 & 4.449 \\
\hline & $\Delta R m$ & 30 & 102 & 26 & -258 & -12 & -110 & 144 & 104 & 0.0 & 80 & -46 & -100 & -222 & 182 \\
\hline \multirow{3}{*}{$\begin{array}{l}\frac{3}{0} \\
\stackrel{\underline{L}}{\leq}\end{array}$} & $\mathrm{hm}^{3}$ & 1.800 & 5.038 & 36.806 & 31.682 & 3.652 & 28.635 & 25.265 & 5.050 & 26.356 & 24.915 & 25.513 & 27.178 & 197.613 & 154.277 \\
\hline & $\mathrm{mm}$ & 1289 & 1420 & 1492 & 1283 & 1363 & 1160 & 1023 & 1016 & 1067 & 1009 & 1034 & 1102 & 8007 & 6251 \\
\hline & $\%$ & 9.0 & 10.0 & 10.5 & 9.0 & 9.6 & 8.1 & 7.2 & 7.1 & 7.5 & 7.1 & 7.2 & 7.7 & 56.2 & 43.8 \\
\hline \multirow{3}{*}{ 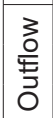 } & $\mathrm{hm}^{3}$ & .060 & 32.521 & 36.164 & 38.049 & 33.948 & 31.350 & 21.711 & 22.483 & 26.356 & 22.941 & 26.648 & 29.646 & 203.092 & 149.785 \\
\hline & $\mathrm{mm}$ & 1258 & 1318 & 1466 & 1541 & 1375 & 1270 & 879 & 912 & 1067 & 929 & 1080 & 1202 & 8229 & 6069 \\
\hline & $\%$ & 8.8 & 9.2 & 10.2 & 10.8 & 9.6 & 8.9 & 6.1 & 6.4 & 7.5 & 6.5 & 7.6 & 8.4 & 57.5 & 42.5 \\
\hline
\end{tabular}


obtained results corresponded with the values listed in the Hydrological Atlas of Poland (Stachy 1987), where the annual sums of evaporation from the water surface (calculated using the Jurak 1976 method) for the Lake Gardno area ranged from $560-580 \mathrm{~mm}$. On a monthly basis, losses due to evaporation exceeded atmospheric precipitation in the first months of the growing season, i.e. from April to July, and fluctuated in the range of 54$93 \mathrm{~mm}\left(1.338-2.330 \mathrm{hm}^{3}\right)$.

The location of Lake Gardno in the surface drainage system (Drwal 1985; Bajkiewicz-Grabowska 2002) affects the amount of water taking part in the horizontal exchange of water. The location of the reservoir in the estuary section of the Łupawa means it is a recipient of almost the total volume of waters flowing from the river's basin. Therefore, it is evident that the inland water supply plays a dominant role in the lake's balance. In 2003-2007, this inflow amounted to $301.490 \mathrm{hm}^{3}$ of water $(12216 \mathrm{~mm})$, corresponding to $85.7 \%$ of the exchanged volume. This was a similar result to the calculations of Balicki (1980), who in this way estimated the lake alimentation to be $11528 \mathrm{~mm}$. The total volume on the land side was made up mainly of the River Łupawa, contributing on average $260.882 \mathrm{hm}^{3}$ of water per year $(10571 \mathrm{~mm})$. In the total mass of lateral inflow, polder systems delivered an average of $11.854 \mathrm{hm}^{3}$ a year and the immediate catchment of $28.754 \mathrm{hm}^{3}$ (Fig. 3).

In the annual system, fluctuations in the inflow of waters from the basin were associated with the hydro- logical regime of the River Łupawa. The most significant mass of water fell during the cold season, with the maximum in January (Tab. 1). At that time, an average of $31.020 \mathrm{hm}^{3}$ of water flowed into the lake $(1257 \mathrm{~mm})$. The lowest volume, reduced by over $30 \%$ in relation to the winter climax, was reached in the spring and summer months, with a minimum in June. The inflow volume was then at the level of $20.501 \mathrm{hm}^{3}(831 \mathrm{~mm})$.

The estimation of sea-side feeding has become essential for the balance needs of Lake Gardno. The share of sea water in horizontal exchange was set at $10.5 \%$, which is $33.791 \mathrm{hm}^{3}$. The obtained results are $47 \%$ higher than those presented by Balicki (1978) for the years 1966-1970 $\left(17.984 \mathrm{hm}^{3}\right)$.

It was assumed that the intrusion of seawater occurred only when the following conditions were met: the sea level exceeded the water level in the lake, and the volume of river inflow was smaller than the volume formed by the water layer during the periodically dominating sea level above the state of the lake. In this way, days with intrusions when the level in the sea exceeded the water level in the lake by $1-3 \mathrm{~cm}$ were eliminated.

According to the adopted assumption, in the period 2003-2007 the months with the highest preferences for inflow were October (12.7\%) and December (11.8\%), while the lowest number of intrusions of marine waters was recorded in March and April (4.5\%). It follows that the inflows were most frequent in the months of autumn-winter storms, and the least frequent during the

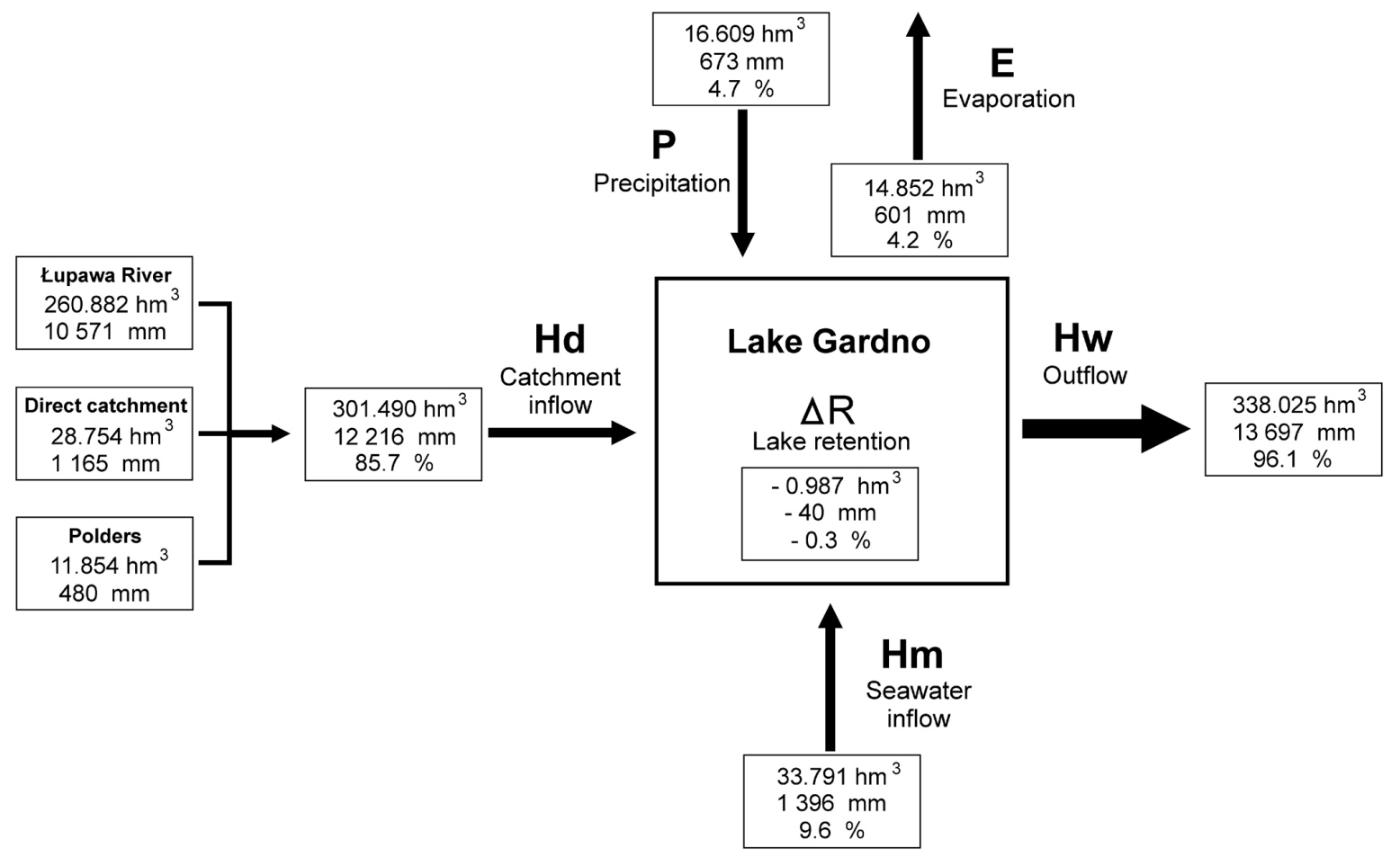

Fig. 3. The average annual water balance of Lake Gardno (2003-2007) 


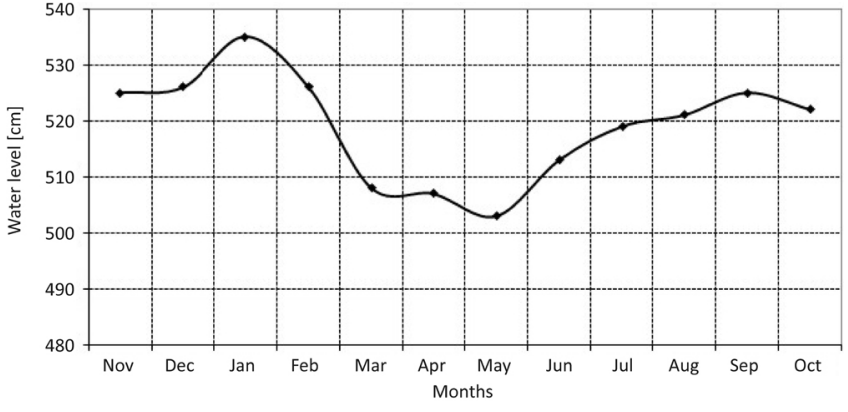

Fig. 4. Average monthly changes in the Lake Gardno water level (2003-2007)

period of outflow of meltwater. However, the volume of waters flowing in differed from the number of intrusions. In this case, the maximum volumes occurred in December $\left(5.928 \mathrm{hm}^{3}\right)$ and November $\left(4.393 \mathrm{hm}^{3}\right)$, and the lowest in August and May, when they did not exceed 1 million $\mathrm{m}^{3}$ (Table 1 ).

In the five-year study, the outflow from the lake, determined from the balance difference, accounted for approximately $96 \%$ of the balance expenditure side. On average, $338.025 \mathrm{hm}^{3}$ of water was discharged from Lake Gardno during the year, which corresponded to a layer of $13697 \mathrm{~mm}$ per one unit of the lake surface. When considering individual months, the largest outflow occurred from November to April, covering almost 60\% of the annual discharge. Its culmination was in February $\left(37.748 \mathrm{hm}^{3}\right)$. The smallest outflow was recorded in the months from May to September, i.e. a period of limited land supply. The minimum was recorded in May.

The obtained values of streams constituting the water balance of Lake Gardno showed that in the period 2003-2007 retention in the cold season was negative and in the summer half-year positive. This proves that despite the increased supply in the winter half-year, especially in February-April, water resources become depleted through increased outflow, leading to the minimum level of the lake in May (Fig. 4). From that moment, water supplied to the lake from various forms of supply was retained, rebuilding resources which translated into an increase in its level. Ultimately, however, the average annual retention volume was negative, and the deficit was $-0.987 \mathrm{hm}^{3}$ of water.

\section{Discussion}

An attempt to evaluate and quantify the water taking part in the circulation in the Lake Gardno basin was the subject of earlier studies by Balicki (1978). Cieśliński (2011) also dealt with the size of the horizontal stream exchange. The obtained results correspond to those presented in this article, but they differ in details. This results from a different methodological approach to determining the components of the balance, as well as the adoption of a different research period. The high compliance concerns the fact that in the entire water balance atmospheric exchange plays a secondary role, while the potamic inflow determines the resources of the lake. A similar ratio of the components of the balance is represented by the neighbouring Lake Łebsko, although in a detailed comparison of the two lakes quite large discrepancies emerge (Chlost 2012).

Differences also appear in the calculation of the inflow from the immediate catchment to Lake Gardno. Cyberski and Jedrasik (1992) assume the value of $26.9 \mathrm{hm}^{3}$ while Cieśliński (2011) gives $16.651 \mathrm{hm}^{3}$. These values, however, do not have much significance in the overall balance of the tested reservoir. A more critical impact on the water cycle in the lake is exerted by the size of the marine intrusion and the impact of the sea in regulating the lake retention level by blocking the outflow. As previously indicated, the obtained results of the seawater supply to the lake are higher than those quoted by Balicki (1978). The outlet part of the River Łupawa connecting both reservoirs and their parameters plays a fundamental role in the hydraulic contact of the lake and the sea. This section is approximately $1.2 \mathrm{~km}$ long, with a width ranging from 15 to $20 \mathrm{~m}$, and even up to $36 \mathrm{~m}$, a depth of up to 2.5 and an average drop of $0.3 \%$ (Bogdanowicz and Izydorek 2012). Additionally, it is oriented towards the north-west, that is towards the winds from the western sector prevailing in this region. Hence, these parameters change quite often. It happens that as the result of storms the mouth of the channel in the fishing port in Rowy is entirely or partially obstructed by sand, as pointed out by Kunisch (1913). In the years 2003-2007, the number of such events was as follows: total sanding - 18 days, partial (one-sided navigable channel) - 114 days, shallowing the entire width of the channel (hindering or preventing navigation - shallowing to $1 \mathrm{~m}$ deep) - 191 days (BPR 2002-2007). Research carried out by the Maritime Office in Koszalin (UMwK 1967) showed that the full sanding of the Łupawa channel occurs mainly in the spring and summer, while partial sanding in the autumn and winter. Thus, this interaction did affect the general conditions of the water circulation in the lake.

Analysing the course of fluctuations in the level of water in the sea and Lake Gardno, there was a high annual, seasonal and daily interdependence. The coefficient of determination of the average monthly sea levels (Ustka) and the lake (Gardna Wielka) from the period 2003-2007 was very high and amounted to $\mathrm{R}^{2}=0.878$. This shows a substantial correlation. It is difficult, therefore, to agree with Balicki's (1978) theorem that "water fluctuations of Lake Gardno are subject only to periodic influences of fluctuations in the states of the Baltic Sea" (page 90, lines 3-4). The obtained results indicate that the 
studied water bodies behave like communicating vessels. Only in certain periods, due to changes in hydrometeorological conditions, interrelationships weaken, but they never completely stop. An even higher correlation with the main drainage base is found in Lake Łebsko with the Pearson correlation coefficient of 0.932 . In this case there was also a significantly higher share of sea waters in the lake's balance sheet, reaching almost 30\% (Chlost 2012). This is due to two reasons: a much larger cross-section of the dampened canal connecting Lake Łebsko with the sea compared to Lake Gardno, and differences in elevation of the water level in lakes in relation to the sea level. In the period 2003-2007, for which balance calculations were carried out, these differences amounted to $13 \mathrm{~cm}$ for Lake Gardno and $7 \mathrm{~cm}$ for Lake Łebsko.

\section{Conclusions}

The balance of the volume of water taking part in the water cycle in coastal Lake Gardno indicated the dominant role of horizontal exchange in the lake. The streams of this phase change seasonally and dynamically, affecting the time needed to completely exchange water in the lake's basin and its hydrological system. While the crucial balance element is the potamic inflow, the main drainage base is of fundamental importance in shaping the water level in the lake. Its role is primarily to form conditions for the outflow of the lake. The neighbourhood and the connection of the lake with the Baltic Sea provide periodic intrusions of sea waters into the lake. Comparison of the volume of this component in the circulation of the waters of two closely located lakes of the coastal zone of the Polish coast (Gardno and Łebsko) emphasises its different share in the total balance of water reservoirs. The contribution of sea waters in the balance of Lake Gardno is almost three times smaller than in Lake Łebsko. This difference exposes the role of local conditions in creating the size of the inflow of marine waters to lakes. These include other parameters of canals connecting lakes with the sea, different location of lakes' water level in relation to the sea level, as well as other morphometric features of lake basins. The above conclusions indicate that each tank of this type should be balanced individually.

The hydraulic connection with the sea guarantees much more favourable conditions for full and quick water exchange than in the case of inland lakes. It means that the retention time in the lake basin is short. The rate of water exchange in Lake Gardno described by the ratio of the volume of water flowing out of the lake to its capacity, underlines the nature of hydrologically active reservoirs (Pasławski 1975). In the 2003-2007 balances, the exchange rate was 10.9 , which equates to nearly eleven exchanges during the year.

\section{References}

Appelo C.A.J., Willemsen A., 1987, Geochemical calculations and observations on saltwater intrusions, I. A combined geochemical/mixing cell model, J. Hydrol. 94 (3-4): 313-330.

Bajkiewicz-Grabowska E., 2002, Obieg materii w systemach rzeczno-jeziornych (Circulation of matter in river-lake systems) Wydaw. Wydz. Geogr. Stud. Reg. UW, Warszawa, 274 pp (in Polish, English summary).

Balicki H., 1978, Wpływ Morza Bałtyckiego na stosunki hydrologiczne jeziora Gardno (Influence of the Baltic Sea on hydrological relations of Lake Gardno) [Dissertation], Uniw. Gdański, Wydz. BiNoZ, Gdańsk, 224 pp (in Polish).

Balicki H., 1980, Metoda obliczania napływu wody morskiej do jezior przybrzeżnych na przykładzie jeziora Gardno (The method of calculating the inflow of sea water to coastal lakes on the example of Gardno lake) [in:] Friedrich M. (ed.) Stosunki wodne w zlewniach rzek Przymorza I dorzecza Dolnej Wisły ze szczególnym uwzględnieniem gospodarki wodnej jezior. Część II (Water conditions in the catchments of the Przymorze rivers and the basin of the Lower Vistula, with particular emphasis on lake water management. Part II), IMGW, Słupsk: 125-133 (in Polish).

Bogdanowicz R., Cieśliński R., 2007, Specyfika problematyki oceny jakości wód jezior przybrzeżnych (Specificity of issues related to the assessment of coastal waters' quality), [in:] Wiśniewski R., Piotrowiak J. (eds), Ochrona i rekultywacja jezior (Protection and reclamation of lakes), PZiTS, Toruń: 11-26 (in Polish).

Bogdanowicz R., Izydorek I., 2012, Słowiński Park Narodowy (Slovincian National Park), [in:] Bogdanowicz R., Jokiel P., Pociask-Karteczka J. (eds), Wody w parkach narodowych Polski (Water in national parks of Poland), IGiGP UJ-KH PTG, Kraków: 281-295 (in Polish).

[BPR] Bosmanat Portu Rowy (Rowy Harbour Administration), 2002-2007, Miesięczne raporty z działalności Portu w Rowach (Monthly reports on the Rowy Harbour operation) [Typescript], Urząd Morski w Słupsku. Inspekcja Administracji Portu.

Burnett W.C., Taniguchi M., Oberdorfer J., 2001, Measurement and significance of the direct discharge of groundwater into the coastal zone, J. Sea Res. 46(2): 109-116.

Chlost 2009, Stany wody i bilans wodny jeziora Łebsko (Water levels and water balance of Lake Łebsko), [in:] Bogdanowicz R., Fac-Beneda J. (eds), Zasoby i ochrona wód. Obieg wody i materii w zlewniach rzecznych (Water resources and protection. Circulation of water and matter in river basins, FRUG, Gdańsk: 211-220 (in Polish).

Chlost I., 2012, Geograficzne uwarunkowania stosunków wodnych Niziny Gardneńsko-Łebskiej (Geographical conditions of water relations in the Gardno-Łeba Lowland) [Dissertation]. Uniwersytet Gdański, Wydz. OiG, Gdańsk, 233 pp (in Polish). 
Chlost I., 2016, Water balance of Lake Łebsko, [in:] Volchak A.A. (ed.), Aktualnye nauchno-tekhnicheskie ekologicheskie problem sokhranienia sredy obitania. Sbornik nauchnykh statei Mezhdunarodnoi nauchno-prakticheskoi konferencii. Chast II (Current scientific, technical and environmental problems of habitat protection. Collection of scientific articles of the international scientific and technical conference. Part II), Izd. BGTU, Brest: 3-8.

Choiński A., 1991, Katalog jezior Polski. Część 1: Pojezierze Pomorskie (Directory of Polish lakes. Part 1: Pomeranian Lake District), Wydaw. UAM, Poznań, 221 pp (in Polish).

Cieśliński R., 2011, Geograficzne uwarunkowania zmienności hydrochemicznej jezior wybrzeża południowego Bałtyku (Geographical conditions of hydrochemical variability of lakes of the southern Baltic coast), Wydaw. UG, Gdańsk, 211 pp (in Polish).

Cieśliński R., Drwal J., Chlost I., 2009, Seawater intrusions to the Lake Gardno, Baltic Coastal Zone 13: 85-98.

Crétaux J.F., Jelinski W., Calmant S., Kouraev A., Vuglinski V., Bergé-Nguyen M., Gennero M.C., Nino F., Abarc R., Rio D., Cazenave A., Maisongrande P., 2011, SOLS: A lake database to monitor in the Near Real Time water level and storage variations from remote sensing data, Adv. Space Res. 47(9): 1497-1507.

Cyberski J., Jędrasik J., 1992, Wymiana i cyrkulacja wód w jeziorze Gardno (Water exchange and circulation in Lake Gardno) [in:] Korzeniewski K. (ed.) Zlewnia przymorskiej rzeki Łupawy i jej jeziora (The basin of the coastal river Łupawa and its lake), Wydaw. WSP Słupsk, Słupsk: 199-220 (in Polish).

Drwal J., 1985, Jeziora w egzoreicznych systemach pojezierzy młodoglacjalnych (Lakes in the exoretic systems of young glacial lake districts), Zesz. Nauk. Wydz. BiNoZ UG, Geografia 14: 7-15 (in Polish, English summary).

Gibson J.J., Birks S.J., Yi Y., 2016, Stable isotope mass balance of lakes: a contemporary perspective, Quat. Sci. Rev. 131(B1): 316-328.

Gibson J.J., Edwards T.W.D., 2002, Regional water balance trends and evaporation-transpiration partitioning from a stable isotope survey of lakes in northern Canada, Global Biogeochem. Cycles 16(2): 10-1-10-14.

Jones H.F.E., Özkundakci D., McBride C.G., Pilditch C.A., Allan M.G., Hamilton D.P., 2018, Modelling interactive effects of multiple disturbances on a coastal lake ecosystem: Implications for management, J. Environ. Manage. 207: 444-455.

Jurak D., 1976, Intensywność parowania z powierzchni wody w zależności od charakteru zbiornika wodnego (Intensity of evaporation from water surface depending on body water features), Pr. IMGW 10: 5-73 (in Polish, English summary).

Kossowska-Cezak U., Bajkiewicz-Grabowska E., 2009, Podstawy hydrometeorologii (Basics of hydrometeorology), Wydaw. PWN, Warszawa, 266 pp (in Polish).

Kunisch E., 1913, Der Gardensee und Gr. Dolgensee. Mit einem anhang: Ein Beitrag zur Kenntnis des Lebasees
(Lake Gardner and Lake Gr. Dolgen. With an appendix: A contribution to the knowledge of Lake Leba), Jahresber. Geogr. Ges. Greiswald 12: 149-233 (in German).

Lichter J., 1995, Lake Michigan Beach-Ridge and Dune Development, Lake Level, and Variability in Regional Water Balance, Quat. Res. 44(2): 181-189.

Mikulski Z., 1970a, Kształtowanie się bilansu wodnego jezior w Polsce (Shaping of water balance of lakes in Poland), Prz. Geogr. 42(3): 433-477 (in Polish, English summary).

Mikulski Z., 1970b, Wody śródlądowe w strefie brzegowej bałtyku (Inland waters in the coastal zone of the Southern Baltic Sea), Pr. PIHM 98: 25-45 (in Polish, English summary).

Mikulski Z., Bojanowicz M., Ciszewski R., 1969, Bilans wodny jeziora Druzno (Water balance of Lake Druzno), Pr. PIHM 96: 73-88 (in Polish, English summary).

Pasławski Z., 1975, Typologia hydrologiczna jezior pojezierza Wielkopolskiego (Hydrological typology of lakes in Great Poland Lakeland), Prz. Geofiz. 20(4): 271-280 (in Polish, English summary).

Recinos N., Kallioras A., Pliakas F., Schuth C., 2015, Application of GALDIT index to assess the intrinsic vulnerability to seawater intrusion of coastal granular aquifers, Environ. Earth Sci. 73(3): 1017-1032.

Rockstrom J., 2004, Balancing Water for Humans and Nature. The New Approach in Ecohydrology, Routledge, London, $247 \mathrm{pp}$.

Rotnicki K., 2008, Przemiany budowy geologicznej i rzeźby obszaru Słowińskiego Parku Narodowego i jego otuliny (Transformations of the geological structure and relief of the Slovincian National Park and its buffer zone), [in:] Florek W. (ed.), Słowiński Park Narodowy. 40 lat ochrony unikatowej przyrody i kultury (Slovincian National Park. 40 years of protection of unique nature and culture), Wydaw. SPN, Smołdzino: 145-183 (in Polish).

Sadat-Nooria M., Santos I.R., Taita D.R., McMahona A., Kadel S., Maher D.T., 2016, Intermittently Closed and Open Lakes and/or Lagoons (ICOLLs) as groundwaterdominated coastal systems: Evidence from seasonal radon observations, J. Hydrol. 535: 612-624.

Stachy J. (ed.), 1987, Atlas hydrologiczny Polski. T. 1 (Hydrological Atlas of Poland. Vol. I), Wydaw. Geol., Warszawa, $79 \mathrm{pp}$.

[UMwK] Urząd Morski w Koszalinie (Maritime Office in Koszalin), 1967, Badanie zabezpieczenia żeglowności wejścia do portu rybackiego w Rowach. Projekt Nr 8830/ GP-SH (Study on securing the navigability of the enter to the fishing harbour in Rowy. Projekt Nr 8830/GP-SH) [Typescript], BPBM w Gdańsku [Available in: Archiwum Urzędu Morskiego w Słupsku (Archive of the Maritime Office in Słupsk)].

Weber M., 1973, Próba obliczenia bilansu wodnego jeziora Łebsko (Attempt of water balance calculation of the Łebsko lake), Wiad. Sł. Hydrol. Met.. 9(4): 69-73 (in Polish). 
Xu C.Y., Singh V.P., 1998, A Review on Monthly Water Balance Models for Water Resources Investigations, Water Resour.Manag.12(1): 20-50.

Yin X., Nicholson S.E., 1998, The water balance of Lake Victoria, Hydrol.Sci. J. 43(5): 789-811.
Zhang Z., Huang Y., Xu C.Y., Chen X., Moss E.M., Jin Q., Bailey A.M., 2016, Analysis of Poyang Lake water balance and its indication of a river-lake interaction, SpringerPlus 5(1): 1555. 